\title{
THE USE OF HEIGHT AND SQUARED DIAMETER RATIOS FOR THE ESTIMATION OF MERCHANTABLE CUBIC FOOT VOLUME ${ }^{1}$
}

\author{
BY T. G. HONER²
}

\section{ABSTRACT}

Two methods of determining merchantable cubic foot volume have been developed and described. Each method is based on regression functions which describe the distribution of volume over the tree stem and can be applied to an estimate of total volume to compute merchantable volume to specified limits. These functions permit the user to:

a) estimate the volume of any portion of the tree stem defined by two measures of merchantable height;

b) determine merchantable volume to any specified top diameter and stump height.

Additional work is now in progress.

\section{RESUME}

L'auteur décrit deux méthodes qu'il a mises au point aux fins d'estimer le volume de bois marchand. Les deux méthodes se fondent sur des fonctions de régression qui déterminent la répartition du volume le long du fût; elles peuvent servir à trouver une approximation du volume total du fût, afin d'en arriver à calculer le volume de bois marchand qu'on pourra tirer d'un fût ou d'un tronçon de dimensions données. Ces fonctions de régression permettent:

a) d'estimer le volume de tout tronçon du fût dont la longueur est déterminée d'après deux mesures de la hauteur de bois marchand;

b) de calculer le volume de bois marchand, quels que soient la hauteur de la souche et le diamètre marchand.

L'auteur poursuit actuellement ses travaux à ce sujet.

INTRODUCTION

Foresters have long been faced with the problem of obtaining merchantable cubic-foot volumes for varying limits of utilization. Two methods have been developed and are presented in mathematical form to provide the flexibility required to handle this problem.

Method (a) utilizes height ratios (height to merchantable limit/total tree height), while method (b) utilizes squared diameter ratios (merchantable top $\mathrm{dib}^{2} / \mathrm{DBHib}^{2}$ ) to estimate the proportion of total cubic foot volume represented by the limits of merchantability. When used in conjunction with height, and specified or measured top diameters, they will belp the practising forester to:

a) estimate the volume of any portion of the tree stem defined by two measures of merchantable height;

b) determine merchantable volume to any specified top diameter and stump height.

\footnotetext{
1 Department of Forestry, Canada, Forest Research Branch. Contribution No. 616.

2 Research Officer, For. Res. Br., Dept. of Forestry, Canada.
} 
While this preliminary investigation deals with limited data confined to a single species, it is reasonable to assume that the general relationships developed are applicable to other species.

Merchantable volume tables are usually described in terms of a minimum diameter at breast height, a specified top diameter inside bark, and stump height. Standard tables list unit volumes in tabular form by diameter and height classes; each table representing a specified stump height and top diameter(s). Specifications of merchantability may vary according to product and local cutting regulations, and many tables do not reflect current utilization practices. Minore and Gedney (1960) showed that the Girard Form Class Tables do not reflect the current utilization practices in Oregon.

Various techniques have been developed to overcome these difficulties. Hummel, Irvine and Jeffers (1951) presented volume tables to a fixed 3-inch top diameter, but also expressed volumes to a 6- and 9-inch top as percentages of the gross volume to a 3-inch top. Burstall (1955, 1957, 1958, 1959) used graphical techniques to prepare merchantable volume tables by 10-foot height classes and 1-inch diameter classes which show, for each 10-foot merchantable height interval, the cubic foot volume (including stump) and the inside bark diameter at the merchantable height.

The volume tables published by the British Columbia Forest Service (Browne 1962) include conversion factors for trees of average height and 3 degrees of utilization. The merchantable cubic-foot volume can be derived by applying the appropriate factor to an estimate of total tree volume. Each technique described above can give reliable estimates for the specified merchantability level; however they do not provide the flexibility required to convert total volume estimates to merchantable cubic-foot volume for any specified stump height and top diameter(s).

The basic problem was stated in the Report of the Committee on Forest Mensuration Problems (Honer and Sayn-Wittgenstein, 1963):

"We must develop a mathematical tree volume expression which can be efficiently programmed for generally available electronic computing equipment to yield tree and stand volumes from input of tree diameter outside bark, total heights (form estimates optional) and for any demanded stump height and top diameter".

Flexibility, therefore, must be the major characteristic of any system developed to estimate merchantable cubic-foot volume.

\section{METHOD}

In approaching the problem, it was postulated that if relationships were developed to describe the distribution of volume over the tree stem, they could then be applied to an estimate of total volume to compute the merchantable volume to specified limits.

The data for this preliminary investigation were gathered in 1921 and used in constructing the Form Class Volume Tables (Anon., 1948). Eleven white pine trees (Pinus strobus L.) purposely chosen to represent various diameter and height classes were selected from the Ontario data. Measurements included section lengths and diameters inside and outside bark at stump height, breast height, and at each tenth section above breast height. 
The data fell within the following classes:

\begin{tabular}{ccc}
\hline DBHib & Height & No. of Trees \\
\hline 3 & 30 & 1 \\
5 & 40 & 3 \\
5 & 60 & 1 \\
8 & 60 & 1 \\
10 & 70 & 1 \\
11 & 70 & 2 \\
11 & 80 & 1 \\
20 & 100 & 1 \\
$\mathrm{t} \mathrm{o} \mathrm{t} \mathrm{a} 1$ & & 11 \\
\hline
\end{tabular}

\section{Basic Calculations}

The volume of each tree section was computed using Smalian's formula. Section volume and heights, commencing with the stump section, were accumulated to show the volume and height to each section. Ratios of volume, height and squared diameters ${ }^{8}$ were computed to each point on the tree stem where diameter and height were measured. Table 1 shows the form of the basic calculations.

Volume for Any Portion of the Tree Stem Defined by Two Measures of Merchantable Height

Since it is often difficult to measure tree diameters at the limits of merchantability, a method to determine merchantable volume based on the height to the merchantable limit and an estimate of total volume was investigated. The height to the merchantable limit was represented by values of $\mathrm{X}_{1}$ and volume by values of $Y_{1}$ where:

$$
\mathrm{X}_{1}=\frac{\text { Height to merchantable limit }}{\begin{array}{c}
\text { Total tree height } \\
Y_{1}
\end{array}=\frac{\text { Volume to merchantable limit }}{\text { Total tree volume }}}
$$

The relationship between the volume and height ratios was established and Equation 1 developed in the form of

$$
\mathrm{Y}_{1}=\mathrm{a}+\mathrm{bX}_{1}+\mathrm{cX}_{1}^{2}
$$

where $Y_{1}$ is that proportion of the total volume represented by the ratio of merchantable to total height $\left(\mathrm{X}_{1}\right)$. Equation 1 can be modified to account for a stump volume deduction as follows:

Let $\mathrm{X}_{1}$ represent the ratio of merchantable height to total height and $\mathrm{X}_{18}$ represent the ratio of stump height to total height.

a) volume ratio to merchantable height $1=a+b X_{1}+c X_{1}^{3}$

b) volume ratio to merchantable height $12=a+b X_{19}+\mathrm{cX}_{12}{ }^{2}$

\footnotetext{
3 All diameter measurements and ratios derived from them pertain to inside bark measurements. When complementary studies of bark thickness, species and locality are complete, the methods proposed here will be adjusced to account for these factors.
} 


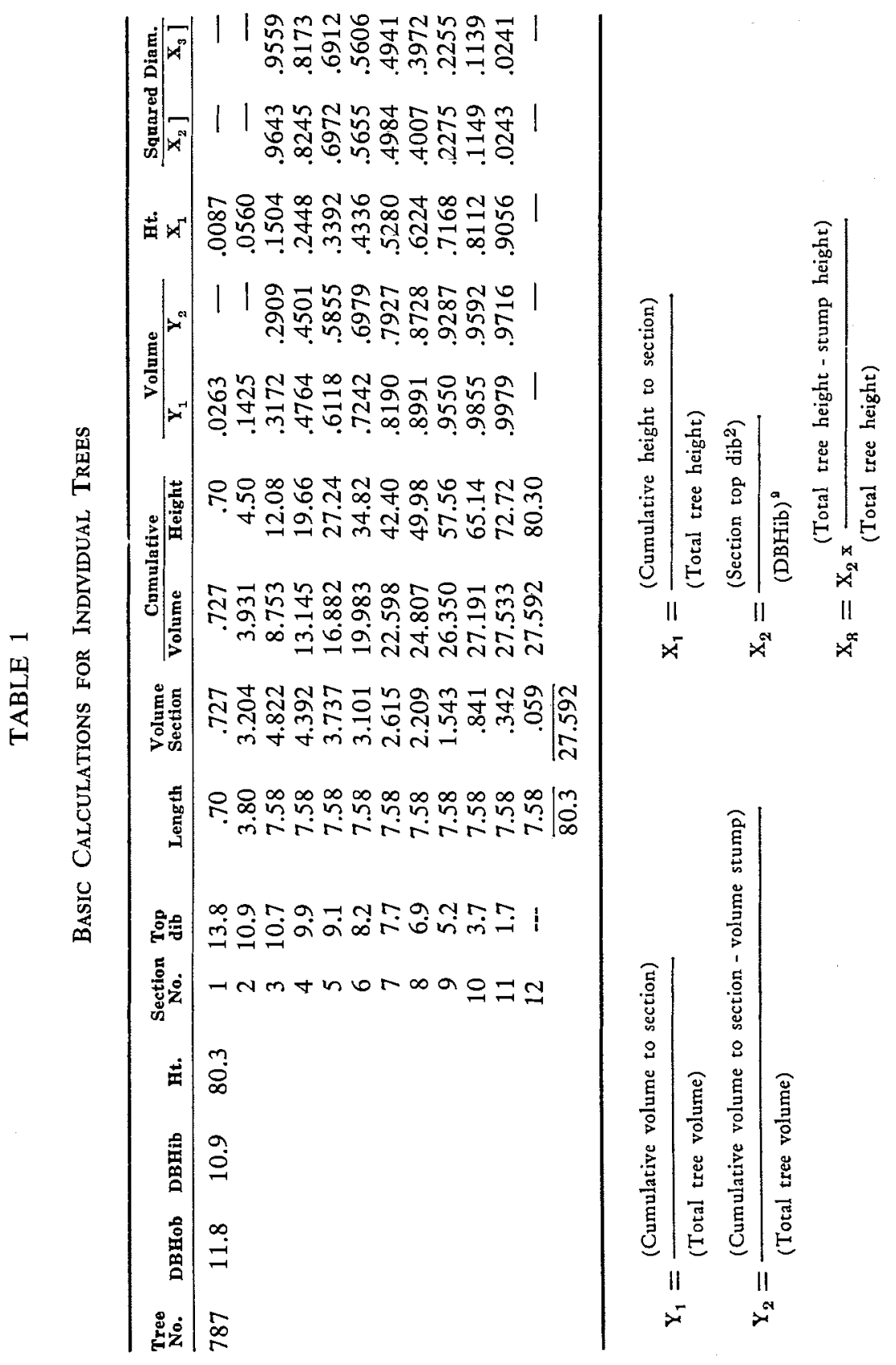


a) -b) proportion of remaining volume $=b\left(X_{1}-X_{12}\right)+c\left(X_{1}{ }^{2}-X_{12}{ }^{2}\right)$

$\therefore \mathrm{Y}_{1}^{1}=\left(\mathrm{b}\left(\mathrm{X}_{1}-\mathrm{X}_{12}\right)+\mathrm{c}\left(\mathrm{X}_{1}{ }^{2}-\mathrm{X}_{13}{ }^{2}\right)\right)$

where $Y_{1}^{3}$ is that proportion of the total volume represented by the ratios of merchantable and stump height to total height.

\section{Volume to Any Specified Top Diameter and Stump Height}

Foresters are well aware that the limits of merchantability for any particular tree will depend in part upon the form of the tree, its branching habit and upon the general condition of the bole. However, volume estimates are often required for specified top diameters and stump heights and in deriving a method to permit the determination of merchantable volume the following approach was considered.

If a relationship between the ratios of squared diameters $\left(\mathrm{X}_{2}\right)$ and the ratios of volume to those diameters $\left(Y_{1}\right)$ were established, it would be possible to determine from a total volume estimate, the merchantable volume to a specified top diameter. The relationship could then be adjusted to account for the volume attributed to the stump section.

Let $X_{3}$ represent the ratio of squared diameters and $Y_{1}$ represent the ratios of volume to that merchantable diameter limit where:

$$
\mathrm{X}_{2}=\frac{\text { Merchantable top } \mathrm{dib}^{2}}{\mathrm{DBHib}_{1}}=\frac{\text { Volume to merchantable top }}{\text { Total tree volume }}
$$

The relationship between the volume and squared diameter ratios ${ }^{4}$ was established and Equation 3 developed in the form of:

$$
Y_{1}=a+b X_{2}+c X^{2}
$$

where $Y_{1}$ is that proportion of the total volume represented by the squared ratio of top diameter to DBHib.

To permit the deduction of stump volume it was necessary to adjust the basic data to reflect varying stump heights. The adjustment was accomplished as follows:

(i) The stump volume ratio (stump volume/total volume) of each tree was subtracted from each section volume ratio. Adjusted volume ratios were designated as $Y_{:}$.

-

- Section $Y_{2}=$ Section $Y_{1}$-(stump volume/total volume).

(ii) The squared diameter ratio of each section was reduced by a factor representing the height of the tree above stump height. Adjusted ratios were designated as $\mathrm{X}_{\mathrm{s}}$.

$$
\therefore \text { Section } X_{s}=\text { Section } X_{2} \times\left\{\frac{\text { Total height-Stump height }}{\text { Total height }}\right\}
$$

4 Values representing the tree tip, breast height, and sections below breast height were not included in the regression. 
Table 1 shows an example of the computations performed for each section of the tree and Equation 4 was subsequently developed.

$$
\mathrm{Y}_{2}=\mathrm{a}+\mathrm{bX}_{\mathrm{s}}+\mathrm{cX}_{\mathrm{8}}^{2}
$$

where $Y_{3}$ is that proportion of total volume represented by the squared diameter ratio adjusted for stump height.

\section{DisCUSSION AND APPLICATION}

Gevorkiantz and Olsen (1955), in preparing their composite volume tables, developed a height utilization volume relationship based on taper curves to estimate the cubic foot content for various sections of the tree stem. A comparison of the values developed by Gevorkiantz and those developed for the 11 white pine showed differences of less than plus or minus $4 \%$ of the estimated pine values.

When Equation 2 was applied to the basic data, all deviations fell within plus or minus $11 \%$ of the estimated volumes. A maximum range of plus or minus $51 \%$ was required to accommodate the deviations of Equation 4. A review of the data showed that these large deviations generally occurred in large trees and for $X_{3}$ values of .5 and greater. It should be noted however, that as long as the $X_{3}$ values represented a substantial proportion of the tree volume $\left(\mathrm{X}_{3}\right.$ values of 0.5 and smaller $)$ percentage deviations were well within the $10 \%$ range.

In determining merchantable cubic foot volume, each of the functions may be used directly (in equation form) or tables of conversion factors for various merchantable specifications may be prepared. Table 2 shows conver-

TABLE 2

Conversion Factors for Ratios of Merchiantable to Total HeIght AND $1.0^{\prime}$ STUMP Height

\begin{tabular}{|c|c|c|c|c|c|c|c|c|}
\hline \multirow{2}{*}{$\begin{array}{l}\text { Ratio } \\
\text { Merch. } \\
\text { Height } \\
\text { to total } \\
\text { Height }\left(\mathbf{X}_{1}\right)\end{array}$} & \multicolumn{8}{|c|}{ TOTAL HEIGHT } \\
\hline & 40 & 50 & 60 & 70 & 80 & 90 & 100 & 110 \\
\hline .1 & .1504 & .1609 & .1672 & .1735 & .1778 & .1799 & .1820 & .1842 \\
\hline .2 & .3304 & .3408 & .3472 & .3535 & .3578 & .3599 & .3620 & .3641 \\
\hline .3 & .4869 & .4974 & .5037 & .5101 & .5143 & .5164 & .5185 & .5207 \\
\hline .4 & .6200 & .6305 & .6368 & .6431 & .6474 & .6495 & .6516 & .6538 \\
\hline .5 & .7296 & .7401 & .7464 & .7528 & .7570 & .7591 & .7613 & .7634 \\
\hline .6 & .8158 & .8263 & .8326 & .8390 & .8432 & .8453 & .8475 & .8496 \\
\hline .7 & .8785 & .8890 & .8954 & .9017 & .9059 & .9081 & .9102 & .9123 \\
\hline .8 & .9178 & .9293 & .9346 & .9410 & .9452 & .9474 & .9495 & .9516 \\
\hline .9 & .9337 & .9442 & .9505 & .9568 & .9611 & .9632 & .9653 & .9675 \\
\hline
\end{tabular}

$\mathrm{Vmcf} / \mathrm{Vtcf}=\left(\mathrm{b}\left(\mathrm{X}_{1}-\mathrm{X}_{12}\right)+\mathrm{c}\left(\mathrm{X}_{1}^{\mathrm{g}}-\mathrm{X}_{12}{ }^{2}\right)\right)$

$\mathrm{b}=2.1515$

$c=-1.1724$

$$
\mathrm{X}_{1}=\frac{\text { Height to merchantable limit }}{\text { Total height }} \quad \mathrm{X}_{12}=\frac{\text { Stump height }}{\text { Total height }}
$$


sion factors (Vmcf/Vtcf) developed from Equation 2, for a specified stump height and ratios of merchantable to total height, while Table 3 shows the conversion factors developed from Equation 4, for specified stump heights and a 4.0-inch top diameter. Note that the conversion factors tend towards a constant level as size increases.

TABLE 3

CONVERsion Factors for a 4.0" TOP Diameter and Various Stump Heights

\begin{tabular}{|c|c|c|c|c|c|c|c|c|c|c|c|}
\hline \multirow{2}{*}{ DBHib } & \multirow{2}{*}{$\begin{array}{c}\text { Stump } \\
\text { Ht. }\end{array}$} & \multicolumn{10}{|c|}{ TOTAL HEIGHT } \\
\hline & & 20 & 30 & 40 & 50 & 60 & 70 & 80 & 90 & 100 & 110 \\
\hline \multirow[t]{4}{*}{5} & .5 & .65 & .65 & .65 & .64 & .64 & & & & & \\
\hline & 1.0 & .67 & .66 & .65 & .65 & .65 & & & & & \\
\hline & 1.5 & .68 & .67 & .66 & .66 & .65 & & & & & \\
\hline & 2.0 & .70 & .68 & .67 & .66 & .66 & & & & & \\
\hline \multirow[t]{4}{*}{6} & .5 & & .81 & .81 & .81 & .80 & .80 & .80 & & & \\
\hline & 1.0 & & .81 & .81 & .81 & .81 & .81 & .81 & & & \\
\hline & 1.5 & & .82 & .81 & .81 & .81 & .81 & .81 & & & \\
\hline & 2.0 & & .82 & .82 & .81 & .81 & .81 & .81 & & & \\
\hline \multirow[t]{4}{*}{7} & .5 & & .87 & .87 & .87 & .87 & .87 & .87 & .87 & & \\
\hline & 1.0 & & .88 & .88 & .88 & .87 & .87 & .87 & .87 & & \\
\hline & 1.5 & & .88 & .88 & .88 & .88 & .88 & .88 & .87 & & \\
\hline & 2.0 & & .88 & .88 & .88 & .88 & .88 & .88 & .88 & & \\
\hline 8 & All & & .91 & .91 & .91 & .91 & .91 & .91 & .91 & & \\
\hline \multirow[t]{4}{*}{9} & .5 & & .92 & .92 & .92 & .92 & .92 & .92 & .92 & & \\
\hline & 1.0 & & .93 & .93 & .92 & .92 & .92 & .92 & .92 & & \\
\hline & 1.5 & & .93 & .93 & .93 & .93 & .93 & .93 & .93 & & \\
\hline & 2.0 & & .93 & .93 & .93 & .93 & .93 & .93 & .93 & & \\
\hline \multirow[t]{4}{*}{10} & .5 & & & .93 & .93 & .93 & .93 & .93 & .93 & .93 & \\
\hline & 1.0 & & & .93 & .93 & .93 & .93 & .93 & .93 & .93 & \\
\hline & 1.5 & & & .94 & .94 & .93 & .93 & .93 & .93 & .93 & \\
\hline & 2.0 & & & .94 & .94 & .94 & .94 & .94 & .93 & .93 & \\
\hline 11 & All & & & & .94 & .94 & .94 & .94 & .94 & .94 & .94 \\
\hline 12 & All & & & & .94 & .94 & .94 & .94 & .94 & .94 & .94 \\
\hline 13 & All & & & & .95 & .95 & .95 & .95 & .95 & .95 & .95 \\
\hline 14 & All & & & & .95 & .95 & .95 & .95 & .95 & .95 & .95 \\
\hline 15 & All & & & & & .95 & .95 & .95 & .95 & .95 & .95 \\
\hline 16 & All & & & & & .95 & .95 & .95 & .95 & .95 & .95 \\
\hline 17 & All & & & & & .95 & .95 & .95 & .95 & .95 & .95 \\
\hline 18 & All & & & & & .95 & .95 & .95 & .95 & .95 & 95 \\
\hline
\end{tabular}

$\mathrm{Vmcf} / \mathrm{Vtcf}=\mathrm{a}+\mathrm{bX}_{\mathrm{s}}+\mathrm{cX}_{\mathrm{s}}^{2}$

$\mathrm{a}=0.9526$

$\mathrm{b}=0.0090$

$c=-0.7828$

$\left.\mathrm{x}_{\mathrm{a}}=\frac{(\text { Specified Top Diameter }}{2}\right)$ 
Tables such as these can be prepared for any merchantability limits and one need only apply the factors to an estimate of total volume to determine the merchantable volume in cubic feet. Foresters who have worked with a variety of volume tables will appreciate the fact that the methods described above ensure that merchantable volumes to specified limits will not exceed total volume estimates. When they are used in conjunction with a total cubic foot volume function and field measures or estimates of merchantable height or top diameter, they will help the practising forester to obtain realistic merchantable cubic foot volume estimates.

This preliminary investigation has dealt with limited data confined to a single species; however, it is reasonable to assume that the general relationships developed are applicable to other species. Additional work is being undertaken to expand the scope of this project and to determine the effects, if any, of species and size class on the relationships which have been established.

\section{REFERENCES}

ANON. 1948. Form-Class Volume Tables (second edition). Dominion Forest Service, Dept. of Mines and Resources, Ottawa, Canada.

BROWNE, J. E. 1962. Standard cubic foot volume tables for the commercial tree species of British Columbia. Forest Surveys and Inventory Division, B.C. Forest Service.

BURSTALL, S. W. 1955. Combined taper and volume tables for Pinus ponderosa and Pinus nigra var. calabrica-Southland. Forest Research Institute Note 3. New Zealand Forest Service.

BURSTALI, S. W. 1957. Combined taper and volume tables for Pinus ponderosa - Rotorua, 1956. Unthinned stands. Forest Research Institute Note 10, New Zealand Forest Service.

BURSTALL, S. W. 1958. Combined taper and volume tables for European larch-New Zealand, 1956: All stands. Forest Research Institute Note 14, New Zealand Forest Service.

BURSTALL, S. W. 1959. Combined taper and volume tables for Pinus radiata-New Zealand, 1957: Shelterbelts; and for Pseudotsuga taxifolia-New Zealand, 1958: All stands. Forest Research Institute Note 19, New Zealand Forest Service.

GEVORKIANTZ, S. R. and L. P. OLSEN. 1955. Composite volume tables for timber and their application in the Lake States. Technical Bulletin 1104. Forest Service, U.S. Dept of Agriculture, Washington, D.C.

HONER, T. G. and L. Sayn-Wittgenstein, 1963. Report of the Committee on Forest Mensuration Problems. Jour. of Forestry, Vol. 61, No. 9.

HUMMEL, F. C., T. W. IRVINE and J. JEFFERS. 1951. General volume tables for Douglas fir in Great Britain. Forestry Commission Record 15.

MINORE, D. and D. R. GEDNEY. 1960. Merchantable Height of Trees in Oregon-A Comparison of Current Logging Practice and Volume Table Specification. Pacific Northwest Forest and Range Experiment Station. No. 184. 